UCRS -53561

DeC5 001936

\title{
Report of the \\ Long-Range Planning Committee
}

Manuscript date: July 1, 1984

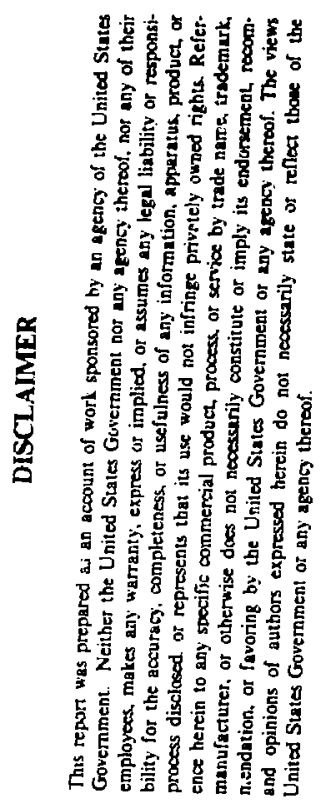

\section{LAWRENCE LIVERMORE NATIONAL LABORATORY University of California - Livermore, California - 94550}

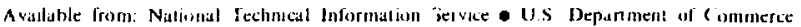

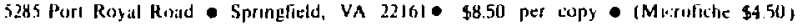

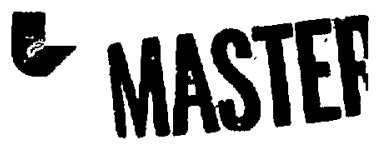




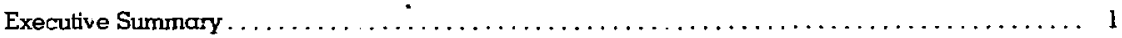

1. Introduction $\ldots \ldots \ldots \ldots \ldots \ldots \ldots \ldots \ldots \ldots \ldots \ldots \ldots \ldots \ldots \ldots \ldots \ldots$

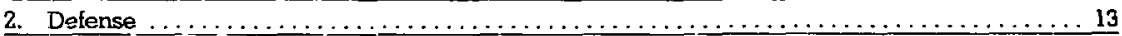

Strategic Deterrent Forces $\ldots \ldots \ldots \ldots \ldots \ldots \ldots \ldots \ldots \ldots \ldots \ldots \ldots \ldots \ldots \ldots \ldots \ldots$

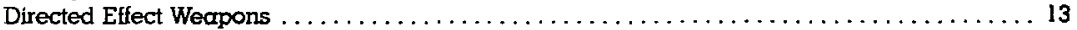

Facilities for Advanced Weapons Expenments $\ldots \ldots \ldots \ldots \ldots \ldots \ldots \ldots \ldots \ldots \ldots \ldots \ldots$

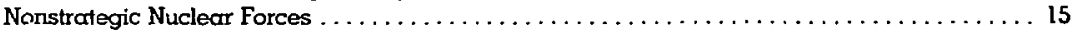

The Conflict Simuletion Center and Tacticar Nuclzar Weapors $\ldots \ldots \ldots \ldots \ldots \ldots \ldots \ldots$ I5

Electromagnetic Effects of Nuclear Explosions $\ldots \ldots \ldots \ldots \ldots \ldots \ldots \ldots \ldots \ldots \ldots$

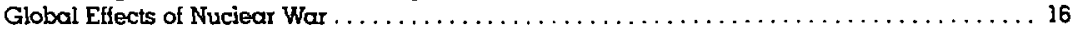

Inertial Confinement Fusion and Weapons $\ldots \ldots \ldots \ldots \ldots \ldots \ldots \ldots \ldots \ldots \ldots \ldots \ldots \ldots$

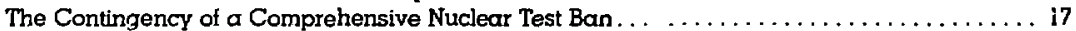

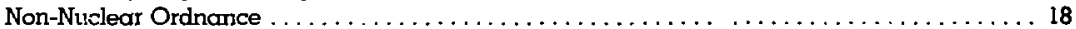

Attitudes Towards the Nuclear Weapons Program $\ldots \ldots \ldots \ldots \ldots \ldots \ldots \ldots \ldots \ldots \ldots$

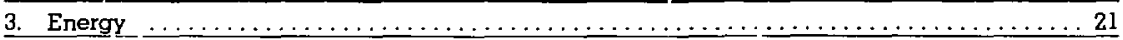

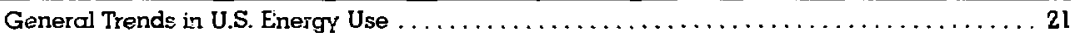

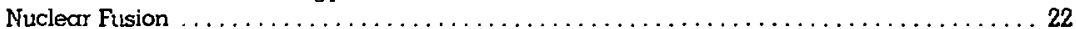

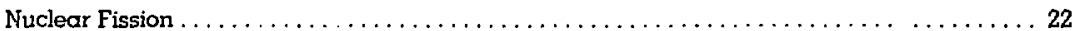

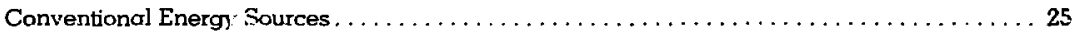

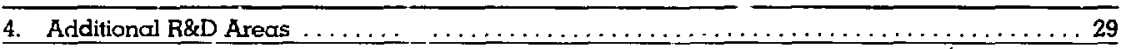

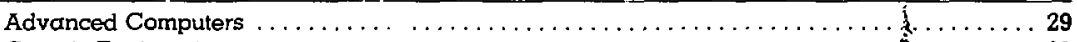

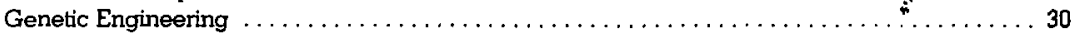

Space Nuclear Fower and Other Space Activities $\ldots \ldots \ldots \ldots \ldots \ldots \ldots \ldots \ldots \ldots \ldots$ I

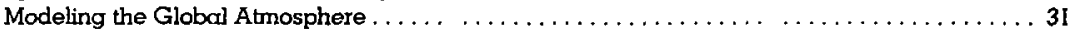

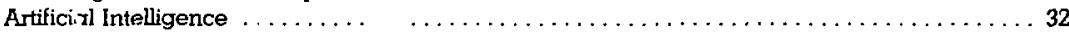

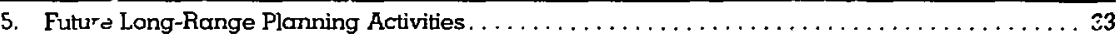

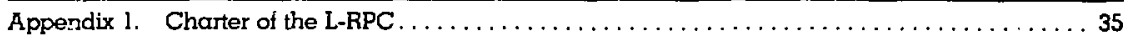

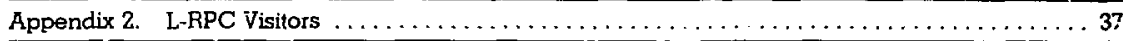




\section{Charter and Scope}

The Long-Flange Planning Committe'e (L-RPC) of the Lawrence Livermore National Laboratory was established on October 19, 1981, by Director Roger Batzel in order to help assure that the Laboratory remains a major contributor to national $R \& D$ and a challenging place to work. The following specific tasks were assigned the Committee:

1. Identily, anclyze, and evaluate possible new programs approptiate to the Laboratory taking into account significant national needs and relevant scientific developments.

2. Help the Director evaluate the likely areas of major programmatic change fo: the Laboratory for the next 10 years.

3. Assist the Director in developing an improved overall piciure of the Laboratory's future needs with regard to people, sites, and facilities.

This report addresses the first and second tasks to which the bulk of the effort was devoted.

The Committee's membership and staft consisted of scientists and engineers drawn from most of the programs and most of the disciplines at the Laboratory. The majority continued to hold full-time manager ent and/or scientific positions through the two-year perioc' that the L-RPC met. The chairman, executive se:retary, and two staff worked half or more time, as did, for periods of weeks or months. the members of study groups sponsored by the Committee.

The Committee made the working assumptions that the Laboratory would continue to have nuclear weapons research and development as its major task and would continue to work for the U.S. Government on applied science and engineering projects. Under these assump. tions, the Committee examined the future of major programs, the possibilities inherent in a number of smaller projects and the desirable areas of emphasis for supporting research. The full report summarizes this work.

The report is divided into three sections: celense, energy, and other $\mathrm{R} \& \mathrm{D}$ areas. 


\section{Defense}

The principal conclusion reached in the defense area was that the Laboratory program in nuclear weapons should continue to be a balanced one, with top-quality effort and high priority devoted to the maintenance of survivable strategic offensive nuclear forces. Nuclear weapons design, understanding of nuclear explosions and their effects, and assessments of the survivability and effectiveness of new strategic weapons systems fall in this hign-priority category.

Strategic delensive systems, if they are adequately survivable and cost effective, offer opportunities to limit the damage due to nuclear war and, in conjuriction with survivable offensive forces, to stabilize turther the deterrent balance. The techrical and strategic possibilities justify major experimental and calculational programs. In add;tion, a system study taking into account the evolution of all relevant technologies is needed and has been started.

The nuclear-explosive-driven $\mathrm{x}$-ray laser could have important capabilities as a component of a weapons system. It is first of all an extremely interesting developmer in physics, the applications of which are not yet clear. The $\mathrm{x}$-ray laser is likely io be a major factor in nuclear explosive R\&D for the next several :'ears.

The Committee evaluated laboratory facilities needed in order to further understar ding of these advanced nuclear weapon concepts. veveral existing facilities at the Laboratory and elsewhere are necessary to improve our knowledge of important physics parameters. The Committee recommends acquisition of a second 10-beam target chamber for the Nova laser facility to do high-energy density experiments vital to $\mathrm{x}$-ray lasers and to the general understanding of other advanced weapon concepts. Procurement of the additional target chamber will increase by more than $50 \%$ the data output of Nova with only a $20 \%$ cost increase. In addition, this and subsequent studies have pointed out the potential utility of a smaller, few kilojoule laser to be used over the long term for research by the weapons and laser programs, by the Physics Department, and by outside users. In the longer term, a larger laser facility ( 5 to 10 megajoule) could allow experiments to be done under conditions which are similar in important parameters to those of a nuclear explosion. Such experiments could be particularly helpful in the event of further restrictions on nuclear tests. 
Tactical nuclear weapons for nonstrategic forces play a role in deterrence which, though difficult to assess, could be essential. Their deterrent role cannot be filled by conventional forces, however effective. Their deployment and modernization have faced and will probably continue to face military, political, and technical difficulties. Solving the technical problems without also solving the military and political problems is not useful. The Laboratory has a tool in early development which can help elucidate the military application difficulties - the interactive, computerdriven Combat Simulation Center. The Laboratory weapons program leadership should work with Department of Defense leadership to make fuller use of this tool.

The Laboratory has used its resources to work on broader questions associated witn nuclear weapons. It must continue to do so. Carrying out analysis of the utility of defensive and other weapons technologies, participating in the evaluation of global effects of nuclear war, and supporting the Government's efforts in the arms control area are major instances of such work likely to increase in importance over the next decade.

The Laboratory's work in the nuclear weapons area should continue to be supported by as open and informative a public information program as possible. In addition, $\therefore$ e Laboratory should increase interactions with the public policy communities in academia as well as in the Government, through a concerted program of visits, internships, and conferences, as these interactions are needed by both these communities and by the Laboratory.

The Committee has looked at a number of other delense areas. Among the mast promising is the development of advanced (higher power density, higher efficiency) solid-state lasers, particularly for applications to targeting and communication problems; and the further exploitation of the Advanced Test Accelerator to investigate particle beams and free-electron lasers. In addition, there is potential for continued important work in non-nuclear ordnance and in the electromagnetic effects of nuclear explosions.

Work for the Department of Defense has become a sufficiently large (about $\$ 50$ million), growing part of the Laboratory's effort that it warrants consisient, conerent Laboratory-wide planning and policy guidance. The Committee recommends that steps be taken to provide this planning and guidance under an existing or new Associate Director. It is particularly necessary that the Laboratory avoid competing with industry, but instead work with the DOD and the Services in defining and carrying out tasks to complement industry's role. 


\section{Energy}

In the energy field, the Laboratory's main programs are in fusion, although fission fuel and fission powerconnecled programs are now running fusion a close second. Fossil fuels (coal and oil shale) are a distant third, at a few percent of nuclear energy programs.

Most of the Laboratory's programs aim at an improved electricity supply. The Committee agrees with the view that electrical demana is likely to grow in the U.S. and abroad, although the timing and extent of this growth are not reliably predictable.

The two fusion programs, the magnetic mirror program which is part of the national Magnetic Fusion Energy (MFE) Program, and the laser program which is part of the Inertial Confinement Fusion (ICF) effort, are very different from each other in the physics they exploit, in their relative advantages as electrical power generators, and in how they are supported. Both have sufficiently different advantages from their main competitor, the Tokamak, to have warranted continued support in the U.S. and abroad.

The difficulties all these approaches, including the Tokamaks, face are that:

- further experimental facilities will be very expensive and

- considerable inventive work is needed if the eventual cost of fusion-generated electricity is to be competitive with that of fission and coal-generated electricity.

In the near term (the next few years), a greatly improved data base should become available through new facilities (MFTF-B and Nova), and through further emphasis on detailed numerical modeling. In the longer term, progress toward lower-cost reactor designs will require more manpower and innovative ideas, as well as collaboration between the two fusion programs and the industrial community. The Committee recommends that work on a broad range of concepts be continued or expanded as appropriate. While the main-line approaches will give essential feasibility data soonest, they may not lead to the most practical or economic fusion reactor.

In addition, one application of fusion technology, the fusion-fission hybrid breeder, holds the promise of contributing to the supply of elertricity in the first quarter of the next century. The fusion-fission hybrid breeder is potentially a more efficient fuel supplier than the fast breeder. and may become economically competitive at an earlier date. It is also more capable thrn the fast breeder to meet a 
rapid increase in the need for fuel, should the construction of nuclear reactors turn sharply upwards at some time in the future.

The Committee has completed a study of the circumstances under which a fusion-fissi a hybrid would be economically advantageous. While such circumstances and their timing cannot be reliably predicted, the results look quite promising based on current understanding. To realize the fusion hybrid's potential, preliminary materials studies and calculations on competitive designs are neederi early on. Such studies, along with continued work on the scientific feasibility of fusion, are necessary if the option of economically attractive hybrid-produced fuel is to be available in the next 30 to 40 years. The studies should be an important new area of emphasis for the fusion programs.

The Committee reviewed the fission-related programs at the Laboratory (the Atomic Vapor Laser Isotope Separation Program, the Nuclear Systems Safety Program and the Nuclear Waste Management Program). These programs all meet the criteria of being based on good technical concepts, meeting a growing need, and being suited to the Laboratory. The Commitiee also investigated other areas where the Laboratory could contribute to national activities related to fission energy. The Committee's study gave insights into subareas, in particular pyroprocessing and altemative power reactor designs. However, much more work is needed to definitely identify what programs might be suitable for the Laboratory.

The in situ coal gasification program has been technically successful over the years, but suffers from reduced support. It continues to be potentially important to the country, and it continues to require a series of fairly largescale field experiments. Much more investment and initiative are needed if answers are to be forthcoming in this area before the turn of the century.

The Committee identified possible new research topic: in coal utilization and in associated environmental effects. These topics include fouling and slagging in coal combustion; characterization of contaminants and poisons in coal; particulate and gaseous emissions from coal fired plants; and atmospheric processes and environmental impacts of acid rain and other emissions, with emphasis on the western United States. These topics are not likely to become large projects in the near future, but, together with the ongoing wil shale project they could provide a diversi. fied and nationally useful fossil fuel program for LLNL. 
The energy field is diverse, and success in it depends on many different social, economic, and technical factors. Given the uncertainties and the promise, we recommend that a small group (two or three people, supplemented by others as needed for specific studies) carry out assessments relevant to future Laboratory activities in this field. This step would be a part of implementing a more general planning recommendation which is made below.

\section{Other R\&:D Areas}

In supporting research for present and future Laboratory programs, the standout candidate for consolidation and expansion is scientific computing. Computing $R \& D$ here is to be understood, broadly, to include work on everything from mathematical algorithms to operating systems and specialized architectures. Future computers can be much more effective for scienific applications than the existing ones. To be much more effective, however, they will place new demands on algorithms, languages, operating systems, and architecture. The Laboratory can be and should be in the forefront of this work. The recent appointment of the Associate Director for Computations, a decision which resulted in part from Commltee work, is a necessary step toward this goal.

In the area of quantum optics, the Laboratory has two very successful large programs, Inertial Confinement Fusion and Laser Isotope Separation, both of which have significantly advanced the state of the art, experimentally and theoretically. We recommend that more resources be devoted to studies of the future applications of quantum optics, both in defense and energy. Studies of that type led to prior successes.

In the life sciences, the Committee, in conjunction with the Biomedical Program, investigated the application of genetic engineering to both Biomedical Program objectives and to other areas in the Laboratory. Support was found to start work in this field. The outlook is promising. The results should be reviewed at regular intervals by the Director or a designate, with particular emphasis on identifying specific applications which can be of importance to Laboratory programs.

Though space research has not been a major locus if work at the Laboralory lor many years, the Laboratory has made numerous importanl scientific and engineerıng contributions since the earliest days of the U.S. space program. Since utilization of space will be increasingly important, the 
This is the final report of the Long-Range Planning Committee of the Lawrence Livermore National Laboratory. It describes the make-up, purpose, working assumptions, and activities of the Committee (Section 1) and discuss the work done by the Committee on delense matters (Section 2), energy (Section 3). a number of additional topics (Section 4), and future long-range planning activities (Section 5)

The Committee was established by Director Roger Batzel in October 1981 (see Appendix 1 for the Charter) and worked through the first few months of 1984. It was chaired by Michael May with Carl Haussmann as Vice Chairman. There were an additional twelve members, three fulltime staff, and an executive secretary. The full membership is shown on the following page.

The Committee worked closely with the Associate Directors and other programmatic leaders. It is not always possible to draw a line between what the Committee did alone and what was done by or in cooperation with other elements of the Laboratory leadership. This report is, in large measure, an account of cooperative endeavors.

The Committee was tasked to look at the long-term future of the Laboratory from a programmatic standpoint. Additional planning efforts are carried out by other Committees and by individuals to look at the lony-term future $c t$ site, facilities, personnel mix, and institutional relations. All these efforts ase brought tingether at the Director's level and enter into the formulation of decisions

The main purpose of long-range programmatic planning is to identify promising and appropriate areas of laboratory work over the long term.

"Appropriate" means that several criteria must be met by a proposed project or activity:

- It must be technically sound.

- It must meet a real need, present, or future.

- Funding must be reasonably assured in the longer term.

- The work should be suitable for a national laboraiory and LLNL in particulur.

- It should he compatible with other LLNi, activities and goals.

- The Laboratory should be in o grod competitive position relative to others who rnight do the work.
Not all amas of work which meet these criteria are likely to be funded at the Laboratory. What activities will actually be funded at some given period in the future will depend on external factors such as the relative priority accorded nationally to fulfilling needs in the defense, energy, environmental, and other areas in that period. The interplay of such factors is seldom reliably predicted.

ins a result, it did not seem useful to try to derive from present trends (augmented by some necessarily arbitrary but probably crucial assumptions) what the possibie or desirable programmatic structure of the Laboratory should be at some time in the future. Nor did it seem useful to pick some fixed time period (e.g., the next 20 years) as the planning horizon. It seemed more useful and realistic to concentuate on identifying programmotic areas which seem promising by the Committee's criteria together with the steps which should be taken now to put the Laboratory in a position to realize their promise. The evolving external factors then must be watched to determine when it is timely to expand our efforts in any particular area.

Two working assumptions were made:

- The Laboratory would continue to be entrusted with the task of nuclear weapons research and development, a task which has been its major responsibility since its founding. Seeing that this task is discharged in the appropriate way and at the appropriate level has been considered essential by every Congress and every Administration since World War II. The management of the Laboratory and the Committee assume this will continue to be the case.

- The Laboratory would continue to carry out the bulk of its work for the U.S. Government in the applied sciances and engineering. Discussions with many outside leaders and experts (see $A_{J}$ pendix 2) confirmed our judgment that there is a large amount of work to be done for the Government in the applied sciences and engineering. $A$ switch of a substantial part of our work tc other sponsors or to other fields would be difficult and clouded with uncertrinties. Therefore there is little reason to consider changing either principal contractor or prirıcipal disciplines. 


\section{Committee Membership}

\begin{tabular}{|c|c|}
\hline Michael May (Chairman) & Associate Director at Large \\
\hline Carl Haussmann (Vice Chairman) & Assaciate Director at Large \\
\hline Rober Andrews & $\begin{array}{l}\text { Z Division Leader } \\
\text { (D Division Leader when Committee } \\
\text { start?d) }\end{array}$ \\
\hline Charles Bender & $\begin{array}{l}\text { Head, Chemistry \& Materials Science } \\
\text { Department }\end{array}$ \\
\hline Robert Borchers & $\begin{array}{l}\text { Associate Director, Computations } \\
\text { (Deputy Assoc. Dir., MFE, when Committee } \\
\text { started) }\end{array}$ \\
\hline Paul Chrzanowski & $\begin{array}{l}\text { D Division Leader } \\
\text { (Committee member fron February 1983) }\end{array}$ \\
\hline Lynn Cleland & $\begin{array}{l}\text { Program Leader, Nuclear Systems Suffety } \\
\text { Program }\end{array}$ \\
\hline Robert Clough & $\begin{array}{l}\text { Deputy Associate Director fo: } \\
\text { Weaponization }\end{array}$ \\
\hline James Davis & $\begin{array}{l}\text { Deputy Associate Direc'c r for Laser Isotope } \\
\text { Separation }\end{array}$ \\
\hline John Immele & $\begin{array}{l}\text { B Division Leader } \\
\text { (Committee member from February 1983) }\end{array}$ \\
\hline John Nuckolls & $\begin{array}{l}\text { Associate Diretor, Physics } \\
\text { (X Division Leader when Committee } \\
\text { started) }\end{array}$ \\
\hline Robert Schock & Head, Earth Sciences Department \\
\hline Walter Sa": & $\begin{array}{l}\text { Senior Staff Scientist for Advanced } \\
\text { Program Development, Laser Program } \\
\text { (Committee member from March 1982) }\end{array}$ \\
\hline Bruce Tarler & Deputy Associate Director, Physics \\
\hline
\end{tabular}

Committee Staff

George Bing

Claire Max

Robin Staffin

Karen Kimball

Jay Davis
Executive Secretary

Staff (from November 1982)

Staff

Stafi

Staff (until September 1982) 
Given these assumptions it is clear that the criterion of suitcbility to this Laboratory implies. among other things, compatibility with an onyoing nuclear weapons R\&D program. The iaboratory experience indicales that the existence here o seireral major nonweapons $\mathrm{h} \& \mathrm{D}$ programs in areas al imporiance to the U.S. Government has helped inaintain the viability of the weapons program by permittng hiing in tines of constrained weapons budgets and by providing opportunities to contunue research in relevant fields at times when the weapons program could not suppo: them. At the same tume. the nonweapons prcgrams here hrive benelited from the tachinology base developed by the weapons pingram. $n$-tably in the computing and engneering areas. and hove generally been among the preeminent such elforts nationally

The nuclect weapons program comprises ubout hall of the labroratory. The weapons program leadership curries out a considerable amount of long-range planning on its own. some tomaily. some intormally. The Lung-Runge Planrung Committee has discussed this planning with ali the weapons progrum leaders including therr present program artivities, the major issues they see, and their goals and long-range plans. Braseo on these discussions. the Commitee and the progran leodership lind they are in essenticl agreement on the major issues and the plans to address them. Section 2 on Defense, especially the Eubsections on Strategic Detertent Forces. Directed Effect Weapons, Non-Nuclear Ordnance, and on Attitudes Towards the Nuclear Weapons program zontcin brief discissions of these issues. Section 2 also contains reports of work done by the Conmilter in ccoperction with the programs in certan spectic delense subcreos winch we bolie ie $t \mathrm{t}$ is timely to address

As whth the weapons proyrum. the other large Laboratory progrums. Magnetic Fusion Energy (MFE: hernat Contmement Fusion (ICF). anr: Lase: Isotope Separuturn (L.'SS). do substantial long-range planmug. and the Commitee did not ccisicier duplicatung thuse effors the Committee discissed their planning with the leaders of these prograns. The man ponts of these discussions are preserved in Section ? lnd if Section 3. Sechon 3 begins with a discussion of the overuil energy trents in the U.S. and includes discussions of Lalo. story prograsis un lission and convention. al energy as well as the I Lston area.

Section 4 cuntans evaluations of several R\&D helds which members of the Commantee considered, under the criteria uuthmed in this introduction. Sertion 5 coutans recomt . idatt uns for further bong-range planmmg ectiv.. is 
Committee has taken a limited look at possible future opportunities in space research. Becalise of recently revived national interest in space nuclear power, the Ccmmittee particularly evaluated the possibilities for I.aboratory participation in that field. We found limited opportunities at this time, but recommend monitoring the national effort for future requirements, especially for advanced higherpower reactors where LLNL could contribute.

\section{Future Long-Range Planning}

The Committee believes that the results of taking an objective and reasonably detached lonk at present and possible new Laboratory programs and their long-term future have been generally useful to the management and other elements of the Laboratory. The process hais also been valuable to the Committee members, $\alpha$ number of whom cre in the position of having to carry out the recommendations of the group. The interactions with and advice cund critical comments from numerous distinguished visitors in ivited by the Committee have been quite valuable. The visitor program was well received by all participants and should be continued on a regular basis.

Looking critically at the prospects for exisling and possible new programs has been recognized as a necessity since the early days of the Laboratory. The Commitiee has three recommendations for continuing to improve this process:

1. For existing programs and related lields, the program leaders must continue to assume the responsibility for long-range planning in the broadesi sense. Each of the programmatic and discipline Associate Directors should evaluate the adequacy of their planning tor the future and make adjustments if necessary.

2. In areas outside or overlapping existing programs, the Associate Directors concerned, under the chair of the Director or an Associate Director, should sponsor groups to carry out studies and recommend action. This is specifically needed now in the areas of energy and space.

3. Every few years a new long-range planning committee composed of up-and-coming managers and other knowledgeable concerned professionals should be constituted by the Director to take a Laboratory-wide look at new anci existing programs in the light of recent national irends and to follow up on the recommendations of previous long-range planning groups. 


\section{Strategic Deterrent Forces}

Strategic detertent forces (the ICBMIs, missile s:bmarines, and the bombers) have held the top priority among the nuclear forces in the national planning in the past. Since any defensive systern that could be deployed to protect the U.S. agusinst missiles and bombers will not be completely effective, and since confidence in a strategic defensive system is bound to be limited because of the intrinsis difficulty of the mission and the practical inability to test the system adequately. the U.S. must continue to rely on survivable strategic offensive forces to deter escalation and attack. Of course, in the fulure as now, strategic offensive forces can only be a part of U.S. deterrent efforts.

Deterrent forces must be able to survive ottack and function aiterwards for missions that cannot be fully specified ahead of time. The forces must also be sale, controllable, and economical. The Laboratory has flayed an essential role in :ielping to provide such forces. It should continue to play this role by giving high-priority to work on the changing makeup of these forces. Reductions in veapon numbers that may result from arms control agreements will make it all the more inperative that the remaining systems be able to survive attack and function reliably.

The Laboratory's ability to provide the nuclear designs and modifications essential for a survivable, safe, and reliable set of offensive nuclear systems rests on a base of science and engir. ering which has grown over the last 30 yeas. int remains quite limited as compared with other fields of science and engineering. Part of the limitations sterns from the diffic !ty of the field and part from the small number of laboratories which participate in the work.

The dual nature of the Laboratory's responsibility in the nuclear weapons field, which requires it to provide both the finished designs to the Services and the underlying findings that make new or improved ciesigns possible, has led to a relatively efficient use of the limited amount of resources spent on new devices and associated development. Separating these functions would decrease both the effectivuness with which funds are used and the realism of the researsh and development.

The Committee linds the current udvanced design progiam excellent. Th: current plonning for evolving L.S. strategic forces is of gond quality, but short of resources, given tiee imf-onance of the rask. The Comm tuee recommenus $\mathrm{m}$ re explicit consideration of desirable directions for future deterient forces, given the likely evolution of technology and the likelihood of anns reductions.

For decades, the U.S. approach to the problem posed by nuclear arms has been to combine survivable weapons systems, employinent doctrine airited at deterrence, and a search for equitable arms control agreements. Over the years, this approach has helped the U.S. and the Soviet Union weather a number of crises. It continues to provide part of the framework for peaceful reiations. Equitable arms conurol agreements mean agreements that facilitate deterrence for both sides; minimize the advantage from any attack: and are adequately veridiable. The Laboratory has participated in this effort since Prolessor Lawrence's leadership of the U.S. Delegation to the Conference of Experis in 1958. The Laboratory has been called on to provide personnel to the Delegations and their stalf and to make terhnical contributions that alarify what is possibje is the way of verification, what are the effects of yarious arms control meastires, and the like. There is a close and ongcing interaction between nuclear weapons development and the possibility of arms control. The Laboratory must continue to contribute to this interaction.

\section{Directed Effect Weapons}

Recent developments in directed effect weap. on concepts, both nuclear and non-nuclear, have led to the serious consideration of systems de. signed to defend not only hard point targets, but the country as a whole, including industrial and other solt targets. These concepts are also cpplicable to anti-satellite uses. Because these concepts rely on currently poorly known phenomena they are opening up new fields of physics and physical applications for stuciy. 
In particular, the possibility of building an $\mathrm{x}$-ray laser pumped by a nuclear explosive is a new piece of physics of broad interest beyond the field of nuclear explosions. Clarification of this physics can and should be a prime ynal of the riaclear explosives R\&D program. Other possibilities for directing and transforming the energy fron a nuclear device should also be investigated.

The effectiveness and costs of directed weapons for eventual defensive or offensive systems are not krown. Present assessmenis iridicate that the technologies for these systems are several ordels of magnitude away from being effertive enough or cheap enough to warrant any early deployment. $R \& D$ could change this situation to $a$ considerable degree.

Under these circumstances, iwo interacting xinds of activities are needed: a research program that will determine what is technically possible and a continuing analysis of the system possibiljties that will nelp determine what technical characleristics are important. Both activities are currently under way in the nuclear weapons program on as large a scale as is consistent with the Laborctory's responsibilities in other essential areas, although not as large as could be effectively pursued.

In other direcled-energy programs not involvir.g nuclear weapons (principally the chargedparticle-beam work and its offshout, the free electron laser). the Laboratory is likely to play an increasingly central role because of its unique exrerimental and other capabilities. Yet, there has been much less analysis of what systems are possible and desirable. More systems analysis is necessary if we are to act with full understanding of the consequences of our choices. The ongoing study sponsored by the Military Applications program has this analysis as a priority lask.

\section{Facilities for Advanced Wecpons Experiments}

The Nuclear Design Department, in conjunction with the Long-Range Planning Committ? investigated the need for new, large, experimental facilities for weapons research over the next five years. The study assessed candidate lacilities for their usefulness to Nuclear Design on the basis of cost, availability, and technical risk, focusing specif:ccily on the X-Ray Laser Program. The major findings and recommendations are as follows.

The successful development of the nuclearexplosive-pumped $\mathrm{x}$-ray laser rests in large part on a detailed and comprehensive knowledge of the physics of highly ionized atoms, and on laser design cocies to model the process.

Some atomic dato can be obtcined from ion accelerators. Some can be obtained from advanced ion-trap machines. Tecinologies should be tracked for the present, without committing the Laboratory to purchase at this time.

A Laboratory-wide effort has been uncier way to make a lowenergy laboratory $x$-ray laser by utilizing the Novette laser to energize the laser pump. Laboratory laser experiments can be useful to verity and expand the $\mathrm{x}$-ray laser design code's applicability. They also offer a window on an intes $x \mathrm{l} x$-ray lasing process. In addition, a laboratory $x$-ray laser would se a significant physics achieverient.

The Novette laser, howeve:, is barely adequate to pump an $x$-ray laser. Tc secure adequate time on Nova tc. $x$-ray laser experiment we recommend that the I-boratory procure a second 10-beam target chamber for iluva, which would allow an increase estimated to be between 50 and $100 \%$ in usable laser time.

The estimated procurement cost for a 10 . beam Nova target chamber, with second and third harmonic frequency conversion and supporting diagnostics, is approximately $\$ 34$ million. Thius, a $20 \%$ addition to Nova's basic cost would allow 50-100\% more data output, benefitting the Laboratory weapon program as a whole. Operating costs for target fabrication, experiments, diagnostics, dala reduction, and design would be $\$ 8-$ 10 million per yoar. Additional costs to maintain a seconi target ciamber should be less than $\$ 1$ million per year.

In summary, the following actions are recommended:

1. The Laboratory should procure and maintain a second target chamber for Nova, to help suppoit the weapons nrogram. A smaller, less 
expensive laser should also be procured to maximize the utility of Nova vin preliminary ond upporting experiments

2. The X-Ray Laser Program should continue to use the available ion accelerators and to track advanced ion trap technology to support its atomic physics needs. No major purchase is recommended at this time.

\section{Nonstrategic Nuclear Forces}

Modernization of the nonstrategic nuclear forces has been a major effort in the weapons program over the last decade, and many needs and challenges remain in this area. Replacemeni of aging tactical weapons in the stockpile provides opportunities to improve safety, survivability, and command and control throught technology now available. Examples of this include the use of insensitive high explosive (IHE) wherever it is feasible and the use of insertable nuclear component (INC) concepis to enhance weapon survivability. $\mathrm{IHE}$, which provides enhanced safety against dispersal of hazardous material in accident situations, is being introduced into the field, but a near-complete change of the stockpile may take two decades or more.

Nuclear weapon survivability is the major issue tor our nonsiraiegic forces because c! the limited number of storage sites for nuclear weapons in Europe and the uncertainties associated with tinely dispersal in crisis. The Laboratury conlinuos to work on INC weapon designs that provide the Services the opportunity to develop operational concepts to enhance survivability. One INC idea would permit nuclear-capable missiles to be treated like any other conventional missiles (no classified warhead information or nuclear inaterids in the missile) while the nuclear malerials (without $\mathrm{HE}$ ) could in principle be stored in any of a multitude of possible storage facilities.

The Cornmittee urges continued vigorous pursuit of new concepts for nonstrategic forces coupled with strong system analyses of utility using such iools as the Conflict Simulation Center discussed below.

\section{The Conflict Simulation Center and Tactical Nuclear Weapons}

The Conflict Simulation Center is a computer facility with interactive graphics which has been used for the development of a multisided, playerinterartive facticul war-gaming model (JANUS). An early version of the JANUS model was developed in 1978. The present simulation is capable of examination of combat at the division and lower level (land forces with some air elements) with conventional, chemical, ano' nuclear weapons. However, fallout, rainout, and air support are not yet treated. When these capabilities are added, it is believed that JANUS will provide a realistic battlefield simulation capability.

Military interest in the war-gaming capability developed in the Center has been high. It centers around the ability of the model to help in the training of personnel and the planning of field exercises. Within the Latoratory, it has been useful in examining the utility of modern battlefield nuclear weapons over curtent weapons and operational issues acsociated with battlefield nuclear weapons.

The Committee and the involved pragram leadership considered several options for the future of the Center ranging from a graduul expansion of the simulation to treat lurger combut elements, but with no additional funding, to the establishment of a national center for conflict simulation using both program a ad DOD funding. An intermediate option, involving an extension of the Center capability to the theater level with some additional internal lunding, wus chosen by the program leadership, a choice with which the Committee concurs.

The utilization of tactical nuclear weapons is clouded with uncertainties, whether in Europe, the context in which most studies have been set, or in connection with sea, air, or space conflicts. Study ol tartical nuclear conflict raises major political questions with interrelated technical and military aspects.

Wider use of the Center can help to clarify the :echnical and military aspects. The Center 
could be used to provide insights into such questions as: What are the least vulnerrble NATO weapon systems? What replacement systems should be considered tc: obsolescent Navy and Air Force urits? What are the key differences between nuclear and non-nuclear combat, from both the military and the civilian points of view?

It is nor clear whether the funding profile odopted or the degree and level of Service involvement planned will permit this wider utilization. The division and program leaderships should review this question, perhaps with the help of senior active-duty and retired military officers such as have discussed these matters with the Cornmittee over the past two years. It is quite possible that the Center could complement other simulation facilities elsewhere and that mutually cumplemertary $R \& D$ could be carried out in several places with the ever.tual gcal of developing much more complete models.

Major expansions of facilities beyond the $R \& D$ stage into the educational and training stage should be funded by the Services and extended by contractors in close cooperation with the Laboratory and similar organizations.

\section{Electromagnetic Effects of Nuclear Explosions}

The Laboratory luas in the past made many contributions to the understanding of nuclear weapons effects, especially in areas where stateof-the-art calculations or special experimental equipment were needed. The effect of the electromagnesiir pulse (EMP) from nuclear detonations on $\epsilon$ istronic systems is such on area. Despite two decades of work in many laboratories, the understanding of Eivif effects is generally deemed to be unsatisfactory. The major cause is the complexity of the EMP interaction with most systems of interest. Current understanding of EMP phenomenology is snadequate to model the results of system simulation tests. Moreover, the simulation of the EMP itself falls short in some important parameters.

Areas where the Laboratory can make a contribution are:
- Continuing Laboratory work in nucleargenerated enhanced EMP. System vulnerabilities to EMP are not well understood. New U.S. hardening requirements may depend on the demonstrated feasibility of these weapons.

- Expanded efforts to study EMP phenomenology issues: propagation, coupling, susceptibility, and failure andlysis. There is ongoing work at LINL in tirese areas, and the Laboratory could make a significant contribution to a national EMP program.

- The Addvanced Test Accelerator (ATA) as a simulation source for EMP. According to calculations, ATA's high electric currents and the beam's fast rise time in air generate intense EMP-like fields in the vicinity of the beam. These regions of high field strength could, in principle, serve as simulation volumes for EMP. In addition, bremsstrahlung from scattering foils placed ralong the beam could be useful for source-region EMP similation of effects on cables and other components of similar dimension.

Given that both the Department of Energy and the Defense Nuclear Agency have some continuing responsibility in this and other effects areas, and given the existence of a large communitj of DNA contractors, work in this field at the Laboratory is likely to coritinue to be supported on the basis of specific projects. We recommend that the Associate Director for Defense Systems take on the responsibility of coordinotion, advanced planning, and palicy guidance in this area as in some other areas where the bulk of the support is expected to come from DOD (also see the Subsection on Non-Nuclear Ordnance below).

\section{Global Effects of Nuclear War}

There are curre:at'y large uncertainties in the nature and extent or the global effects of nuclear war. A freliminary assessment, made under the aegis of the Committee and of the Nuclear Weapons and Physics programs, confirmed that in the case of a specified tull-scale nuclear exchange betreen the U.S. and the Soviet Union, the climatic effects in particular, could be serious, under the 
assumptions made about the nature, extent, and location of contaminants released into the atmosphere. Whether these assurnptions are right, however, and quantitatively how serious the consequences are for given assumptions remain highly uncertain. Better calculations and some experiments (non-nuclear) could reduce the uncertainties considerably.

Given the importance of reducing these uncertainties and the Laboratory's experience and resources in the relevont fields, a cortinuing priority effort, specifically in the areas of understanding the source for smoke and gas injection and of two- and three-dimensional, time-dependent atmospheric modeling, seems warranted. This work should not be carried out soleiy at the Laboratory. it only because the Laboratory may not be viewed os a disinterested or totally ubjective party in the results. But the Laboratory has contributed in similar situations in the post and can in this case contribute to the country's understanding of a difficult problem. Contributing to the general un. derstanding will also place the Laboratory in $c$ better position to assist the Government agencies concerned in determining the course of future weapons programs.

\section{Inertial Confinement Fusion (ICF) and Weapons}

The ICF program at the Laboratory has growi from some pivotal early ideas in 1970 to the point where it leads the world in inerial confinement results, laser technology, diagnostics, and computer calculations. The program is following a two-pronged strategy. On one hand, in conjunction with the nuclear design program, it is developing calculational and experimental tools and basic understanding of thermonuclear burn of central imporlance to the design of nuclear explosives. On the other hand, it is pursuing the devalopment of cheaper and more powerful laser drivers, especially at high frequency, both for the purpose of doing higher energy (and therefore more meaningful) experiments in: the laboratory at reasonable capital costs, and for the purpose of developing the luser approach to fusion po:ver.
The outlook for electricity generation $\downarrow$ via ICF is discussed in Section 3. The main tasks of ICF for weapons research are:

1. to formulate a systematic program of weapons physics investigations on the available lasers and

2. to assure that the expertise developed in connection with the program are fully utilized in the weapons design programs. A decision to procure an additional target chamber for the Nova laser should help with the first task particularly.

\section{The Contingency of a Comprehensive Nuclear Test Ban}

Ever since the Laboratory's experience with the Nuclear Test Moratorium of 1958-61 and its aftermath, Laboratory managers concerned with the nuclear weapons program have been aware of the polential impact of a comprehensive nuclear test ban (CTB). Under such a ban, many of the program's responsibilities could not be discharged. Assessments by the Laboratory of the consequences of a CTB have been provided to the Goverriment on many orcasions. The question remains as to what can be done by the Laboratory now to facilitate carrying out its responsibilities in the event of a CTB, responsibilities that are likely to continue to include tasks such as weapons maintenance and modification.

One major problem posed by a CTB stems from the inability of weapons designers to make and certily all changes required by safety, materals deterioration, new configurations, new military requirements, etc., without nuclrar tests. Not all of these changes necessitate a nuclear test, but some do. All of them rely on data obtained from lests and. most c:itrcally, on judgments and insights of scientists and engineers developed thro:igh previous test experience. In the event of $a$ CTB, the dato would not be obiained and the personnel cauld no longer be trained.

There is no completely satisfactory woy to meet these problems. They may be alleviated by such measures as the following: 
- Improvement in the understanding of present nuclear designs, including such basics as equations of state, opacities, radiation transport, instabilities, etc. vic the currently permitted nuclear testing and other means.

- Design of weapons which would be even less likely to suffer material deterioration than current designs and/or which could be modified if need be with less uncertainty about performunce. There would of course be costs in weight, size, and performance associated with such designs.

- Either now or at the time a CTB is in force, acquisition of experimental facilities which might replace to some degree the nuclear lests.

- Major increased emphasis on use of super computers (numerical models) and vigorous pursuit of more advanced computers.

Of these, the first and fourth are being pursued as vigorously as budget renstrictions permit. The second is quite difficult to pursue in the absence of specific knowledge of what future military systems will look like and without significant added funding. The third has been repeatodly examined. No facility was found which could replace nuclear tests to any extent. However, some facilities, such as a large (5-10 megajoule) lisser, would permit experimenters to acquire data relevant to the interpretation of past tests, as well as to maintain some level of relevant skills.

Another major problem posed by a CTB is that it would prevent the exploration of new capabilities and new effects. Of course, to many proponents, that feature is nol a problem but a major advantage. It should be noted, however, that the new capabilities are likely to be either defensive in nature or more discriminate offenses (the destruction of cities requires no further $R \& D$ ). Ignorance of such russibilities does not seem desirabie.

\section{Non-Nuclear Ordnance}

Senior management in the Office of the Secretary of Defense has repeatedly called attertion to the fact that advanced conventional munitions are not being developed and deployed as expected. The technological level of rew munitions has been outstripped by the technology of platforms, such as propulsion and guidance. During the next five years, increases in the DOD funding of work on advanced conventional warheads of about $\$ 400$ million (a factor of 2) have been requested. Expenditures of $\$ 30$ to $\$ 60$ million of this new outlay at the three DOE weapons laboratories can significantly increase the effectiveness of these new technology initiatives.

The DOE weapons laboratories have developed capabilities and facilities as a result of the nuclear weapons design and engineering program which can be applied to work on DOD conventional munitions. The facilities include the CRAY computers for hydrodymamic modeling; bombing and firing ranges adapted to hazardous materials and equipped with high-speed diagnostics and flash radiography; and the facilities needed for fabricating hazardous materials, precision machining developing new materials, and testing them. Laboratory personnel bring to bear a broad array of weapons systems integration experience.

By the same token, advanced conventional munitions work reinforces and broadens the needed capabilities of scientists and engineers in implosion physics, HE chemistry, and mechomical and electrical engineering. It is the hedge against a comprehensive test ban most relevant to these disciplines. Thus, there is a synergism between conventional munitions work and nuclear weapons work.

On the other hand, the system for developing and producing conventianal weapons is quite different from the nuclear weapons development and production system. In particular, there is, with conventional weapons, much heavier reliance on competing industries. The Laboratory must not be put in a position of competing with industry or teaming up with one industry team against another.

The DOE laborateries have already performed conventional warherad research in a number of DOD reimbursable programs. This work and spinstis from the nuclear weapons program 


\section{General Trends in U.S. Energy Use}

Attempts to predict details of U.S. energy usage 20 years into the future are subject to very large uncertcinties. However, based on the experience of the years since the oil embargo of 1973. one can nevertheless make some general statements about trends in U.S. energy use. Consider the 1982 distribution of energy end uses in the U.S. Liquids (mostly oil) sccount for about half the total end use, gases make up about $27 \%$, and electricity about $12 \%$. Caal, hydro, and renewables sum to another $10 \%$. The latest DOE projections to the year 2010* suggest that oil and gas use will shrink in both relative and absolute terms, and that end use of electricity, renewables, and coal solids will expand. Total energy end-use is predicted to grow only slowly, from about 56 quads $^{\dagger}$ in 1982 to about 68 quads in the year 2010 .

Reiative to total primary energy consumed, inputs into U.S. electricity generation have increased from $18 \%$ in 1960 to $33 \%$ today. The DOE projects that electricity inputs will account for $42 \%$ of total primary energy consumption by the year 2000, and predicts an increased role for coal, nidclear, and renewables (currently mostly hydroeiectric) within the electric utility industry.

The U.S. has abundont domestic supplies of coal and enough moderate-cost uranium to last at least another hall century. Because these two resources, together ivith hydro powes, dominate U.S. electricity generation and because they are relatively less expensive than oil and gas, increases in the price of electric energy in the U.S. are projected to remain well below those for other more oil-dependent forms of energy. In addition to lower base cosis of coal and nuclear fuel, environmental considerations may play a strong role in promoting the use of electricity. A central power plant can control pollutants more eccnomically than many smaller units can. Since the electrical

\footnotetext{
- "Energy Projections 10 the Year 2010.' DOE/PL-0629/2. October 1983.

${ }^{t}$ One quad $=1$ quadrillton BTU $=10$ BTU. 4 convemen! urill of large scale energy use.
}

distribution system is already in place, this favors use of elects icity over other sources of energy.

Some consequences fluw from the trends discussed above:

- The IJ.S. economy will depend strongly on the smcoth operation and adequate supply of its elfectric generating system. There will be sensitivity to interruptions due to unreliable or un. safe nuclear and coal flants, bottlenecks in coal transportation, environmental constraints, and lack of adequate reserve margin due to delays in new power plant construction. These areas are high-priority issues in energy planning, and suggest fruitful fields in which energy research might be concentrated. Fission and coal are attractive ureas for the Laboratory for another reason as well. With two large fusion programs which will not produce commercial electricity in the near future, it may be wise for the Laboratory to be involved in some energy research projects which can bear fruit sooner. Fission and coal research can help to add balanre to LLNL's energy research programs. Investigating the applicability of fusion R\&D to effective breeders seems particularly desirable.

- Petroleum-based liquid fuels, constituting half of all U.S. energy end-use in 1982, are predicted to bear the double burden of highest prices and highest potential for supply interruption due to events external to the U.S. A premium is thus placed on research aimed at decreasing the cost and increasing the quality of synthetic liquid fuel forms. On the other hard, present resource estimates for natural gas in the U.S. suggest that a strong need for synthetic natural gas will not arise in the next 15-20 years. * Unless there is a breakthrough which makes synthetic gos less expensive than natural gas of equivalent quality, gaseous synfuels development is likely to proceed at a slower rate than had been furecast in the late 1970's.

\footnotetext{
- "1983 Gas Resecrch Inst Baselin. Frojection of U.S. inergy Supply and Demand. 1982-2000." Gas Research Inst. Ciurctgo, 1983
} 
- A third consequence concerns the more advanced technologies for electricity generation, such as nuclear fusion. In the U.S. of present, coal and nuclear plants are roughly equal in terms of cost of electricity. Both are projected to remain cheaper than oil or gas for generating electricity over the next 20 years. New technologies such as fusion will thus have to show design costs that are competitive with coal and/or nuclear fission, if they are to achieve significant deployment in the economy. This represents an ambitious goal for the two national fusion programs.

\section{Nuclear Fusion}

The Laboratory's magnetic fusion program, bused on the tandem-mirror concepr and its inertial confinement fusion progıam based on lasers have both seen major advances in the recent pust. In the context of reaching the physical parometers that can demonstrate feasibility, each must be considered to be behind the Tokamak loroidal fusion devices. Yet the potential advanlages of mirror or laser-based fusion reactors over Tokamak-based reactors have been sufficient to bring sizeable support for these two altemative concepts. In the next few years, the Laboratory's mognelic fusion energy (MF'E) and inertial confmemenl fusion (ICF) programs will see the advent of major new facilities. The MFTF-B and Novi facilities, logether with the Halite program, should allow substantial progress in evalualing the scientific potential of the two lusion technologins. Planned operational funding is level or shows at best slight increases.

Prosenl reactor studies-which are based on today's enginet ring and physics concepts-show that estimated costs of fusion electricity are roughly 2-3 times. the cost of today's electricity from light-water reactors or trom coal-fired plants. Under such conditions neither MFE nor ICF fusion would be economically attractive. The next decade will be a crucial time for researchers to develop the scientific basis for a substantial reduction in the costs of fusion reactors.

It would thus seem timely lor both the MFE and ICF programs to emphasize imaginative, possibly joint, efforts on the development of potentially less expensive power plant concepts. It is important to look at both improvements on present approaches to containment and at fundamentally different approaches such as compact magnetic fusion machines. The state of the art is not such as to warrant focusing on a single approach.

During the next several years the Laboratory's MFE and ICF programs will be proposing follow-on facilities to MFTF-B and to Nova. The Tokamak program at Princeton has already done so. These facilities should approach reactor-level conditions in many important ways. They will aiso be sufficiently expensive that the case for their construction will have to be quite compelling. A national (or perhaps intemational) approach is needed to the problem of, on the one hand. studying reactor-level conditions in one or more large, expensive facilities; and, on the other, keeping alive and well innovative experimentation on potentially more economical designs. Laboratory monagement should continue to take a leading role in helping to rescive this problem.

\section{Nuclear Firssion}

The Lavoratory's work supporting the civilian and militar: nuclear industries has grown to be the third lc-sest cctivity at LLNL. At present this effort centers on uranium and plutonium enrichnient, the nuclear fuel cycle, and satety issues. While th: future of the commercial nuclear power industry in the U.S. remuins unrertain, the need for work on salety and fuel-cycle problems is expected to increase ovor the next decade. Since the Government has the ultimcte responsibility for safeguards and salety, much of the necessary research will have to be performed at those Government or national laboratories where the skills in handling and onalyzing nuclear materials reside.

\section{Laser Isutope Separation}

At present thr lobordtory's main program concerning the fissim fuel cycle is Laser Isotope Separation. The urumum isolope separation program currently uridfer wory is expected to have a 
finite lifetime at LLNL because this technology will be transferred to appropriate outside institutions once feasibility has been demonstrated. Followon projects in quantum electronics applications are expezted to emerge over the next several years. Potential new applications in the area of uranium isotope separaiion include production of highly enriched uranium for research, fueling of advanced power and militury reactors, and removal of $U^{236}$ as part of uranium recycling procedures. In the area of plutonium isotope separation. potential advanced applications include separation of $\mathrm{Pu}^{23 \mathrm{~d}}$ for use as a radiothermal power source and for improved safety during fabrication of mixed-oxide reactor fuel, and a variety of new plutonium isotope-separation activities with military applicalions.

Other advanced applications arising Irom technologies in LINL's present isotope-separation program may include fission-product utilization. development of structural and operational mater1als for nuclear reactors and fuel cycles, materials handling methods for new reprocessing technologies, selective isotope removal for advanced nuclear waste-management schemes, isolopes for use as tracers in medical research, and nonisotopic, non-nuclear applications of laser photochemistry. During the rext several years, LLNL's isotope separation program must evaluates the relative promise and feasibility of each of these advanced applications. This will necessitate an increase in the resources devoted to advanced applications.

\section{Nuclear `ystems Safery Frogrum}

Work on safety and safeguards for the Nuclear Regulatory Commission (NRC) is presently an impotant part of the Laboratory's effort in the field of nuclear power. The Laboratary has done research for NRC since 1977. Currenty funding is about $\$ 9$ million and it is expected to remain ccustant or possiti; decline slightly with expected decreases in NRC budgets for some years. T: e program is diverse with as many as 30 distinct, rojects, big and small, in areas such as charcictarization of sites in terms of sejstnic re- sponse, structural mechanics. human factors, etc. Success with NRC work has brought additional sponsors for the Nuclear Systems Safety Program (NSSP), including DOE and FEMA.

This NRC program is important to the future of the U.S. nuclear industry, it is considered appropriate for a nationa! laboratory, and it has been reasonably well-funded for some years. The work is compatible with Laboratory skills and interests. LLNL is now well established in this area, and efforts should be made to expand and diversify the support.

\section{Nuclear Waste Management}

Another Laboratory program of significance to the nuclear industry is DOE'a Nuclear Waste Management Program. The Laboratory has been involved in this research, since 1976. With the passage of the Nuclear Waste Policy Act af 1982 , DOE's thrust and the Laboratory's reserarch is now focused on development of actual waste storage sites. LLNL's program is part of a consortium effort with : $\because$, Sandi: and the U.S. Geologicul Survey, $\cdots$ i i guivance from DOE's Nevada Operations Office. Current turding is about $\$ 9$ million ai.d is expected to remain level for some years. LLNL's current primary responsibility is to develop the cctual nuclear wasi: package for emplacement in a Nevada repository. In addition to the engineering design work, LLNL is also doing calculational trodeling research and experimentation on the urderground environment and the movement of radionuclides over long times.

In addition, within this activity there are several promising areas which are likely to receive increased attention in the coming years: advanced waste forms, advanred waste packages to fit within the currently favored mined repository concept, and advanced concepts relatirg to the dispussal scheme itself Waste forms based on stable minerals (such as the successful SYNROC concept developed at LLNL for defense wastesi. wasle packages based on an equilibrium association of components for emplac rment in mued 
geologic repositories, and advanced disposal concepts such as a widely spaced series of deep drillholes instecd ct a mined room, are all viable alternatives to presently favored options. The Laboratory's experience in nuclear waste programs suit it to the development of such advanred concepts.

Like the NSSP activity, this program meets the criteria of suitability for the Laboratory. As with NSSP, the Laboratory's capabilities are not unique, but LLNL is a well accepted and productive partner in the national program.

\section{Pyroprocessing}

At the back end of the nuclear fuel cycle. nonaqueus processing and, in particular, pyrcprocessing of nuclear fuel has polential cost advantages over the present Purex aqueous processing system. Pyroprocessing technology. however, has so far been explojied oniy on small batches of plutonium for military applications. A major technology effort would be necessary before the true polential for large scale processing (and reprncessing) activilies could be evaluated.

The L-RPC, through its Nuclear Energy Subcommittee, has sponsored a detailed internal sludy of the polential of nonaqueous technology for recnvery and purification of materials of interest to defense programs and the nuclear power industry. The study focused on the pyrochemical and pyrometallurgical processes.

Pyroprocessing of detense materials has been applied to various degrees at the Rocky F'lats Plant and the Los Alamos National Laboratory. The L-RPC's evaluation shows that the technology works well and is cost effective for purification and conversion of pluton:um oxides and salts to weapons grade metal. Chemistry research und uperational improvements have been identified as areas for lurther development.

In the area of processing ol irradiated materials such as civilian reactor fuels, comparison of pyroprocessing with the well-understood Purex process shows no net identifiable benefit from the high temperature processes. In operations and maintainability, relative simplicity and use of more common materials at moderate conditions heavily faror the Purex process. Tite pyroprocess shows little or no advantage in required floor space.

By contrast, processing of high bumup fuels discharged from Naval propulsion reactors represents an opportunity that may provide an entry into pyroprocessing of irradiated materials. These spent fuels are very different from those of the light water or liquid metal fast breeder reactor because of their chemical makeup and high fission product content. Purex-like processes can handle these fuels only with great difficulty. Naval reactor fuels will be producet as long as nuclear powered ships are in use, and new reprocessing facilities may be needed in the late 1990's. The Laboratory should investigate the possibility of new pyroprocess development for these fuels.

\section{Power Recctor Designs}

At present, the Laboratory does not have a research effort specifically devoted to fission power reactor design. Yet the fission reactor is the single most important contributor to both the cost and environmental risk of the civilian fission fuel cycle. Hence, development of better reactors is a high-leverage endeavor for the nuclear power industry and the country. Research on reactor improvements may be an important factor in the revitalization of the nuclear power industry

To begin to evaluate whether LLNL might have a role in research on future ission reactors, the L-RPC through its Nuclear Energy Subcommittoe sponsoied a review of major nuclear reactor concepts with regard to possible cost, safety, or other advantages. The study included an analysis of the expected replacement requirements for central electric generating plants.

A method to rate reactor concepts was established. The final reactor ratings show the high temperature, gas-cooled reactors to be superior when evalualed either on the basis of component properties or of overall systern characteristics. Water-cooled reactors rate low based on materals properties, but high based on the performance 
achieved. This good pertormance level for lightwater reactors is of course due to many years of experience and many engineering improvernents. The analysis indiccte: that several advanced types of high temperative, gas-cooled renctors might be safer, more efficient, and more economic than light-water reactors, if they were given equivalent эngineering development.

With the recent cancellation of the Clinch Fiver Breeder Reactor, a window of opportunity may exist for advanced reactor concept proposals. The laboratory should follow development in this area closely over the next year, and should continue to evaluate LLNL's role in the evolving national coniext.

\section{Fission-fusion Hybrid}

Our studies of the fission-fusion hybrid for the breeding of fission-reactor fuel have suggested the possibility of substantial economic and environmental advantages relative to the liauid-metal fast breeder reactor (LMFBR).* Recent advances in the desigr. of fission-suppressed blankets for the fusion hybrid have led to the prediction that one fusion hybrid woula be able to breed enough fuel to provide the annual rakeup requirements of as many as 10-20 lighi wirter reactors (LWRs) of equivalent nuclear power. Such a large "support ratio" would allow the high capital cost of the fusion hybrid to be divided among its $10-20$ client LWRs. Alternatively one hybrid could provide fuel to start up 2-1/2 to 3 new LWRs each year. As a result, a fusion hybrid costing as much as two to three times the ccipital cost of a light-water reactor is predicted to add only $10-20 \%$ to the net systemwide cost of electricity from present-doy LWRs buming mined uranium.

By contrast, presently conceived LMFBRs can breed only enough fuel to support one new LMFBR or LWR every 10-20 years, or to provide the anriual makeup requirements for less than one LWR. Thus the cost of LMFBR-fueled eloctricity is

\footnotetext{
- Report on "Uranium Resources and their Implications for Fission Breeders and Fusion Hybrid Development." by Claire E. Max, (1984) UCRL-90820.
}

dominated by the capital cost of the original LMFBR alone. Since most previctions for the capital cosi of a mature LMFBR are in the range 1.4-2.0 times that of a light-water reactor. " LMFBR electricity is expected to be at least $30-40 \%$ more expensive than present light-water reactor electricity. Thus the fusion hybrid-fueled LWR system is predicted to produce electricity less expensively than presently designed LMFBR systems. If these comparative economic advantages continue to hold true as more realism is added to fusion hybrid designs and as LMFBR designs are im. proved, then one would predict that the fusion hybrid could be economically deployeri as much as 10-20 years earlier than the LMFBR. Further, the hybrid would not suffer the large electricity cost disadvantages of presently conceived purefusion reactors.

This potential is leading to renewed interest in fusion hybrid research. Studies comparing the potential of fusion ard fission breeders should be continued, with the: helF of appropriate outside advisors. The need to lounch a larger fusion hybrid development effort $\mathrm{mo}_{j}$ occur in a few years, if the U.S. nuclear power industry revives and if the U.S. or international fusion programs have demonstroted breakeven or modest gain.

\section{Conventional Energy Sources}

Fossil fuels in the form of coal, gas, and synfuels will play an important role in the future U.S. energy economy. LLNL's role in this field stemmed originally from its knowledge of underground experimentation. LLNL's fossil-fuels research effort is currently funded at about $\$ 5$ million per yerr. LLNL's contribution is recognized as important by industry and other laboratories. The appropriate research areas for the Laboratory are in the longer-term, higher-risk research programs that are difficult for private industry to pursue.

\footnotetext{
- "The Economic Competitiveness of Breeder Reactors Compared to Light-Water Recciors," by Robert L. Cinak, Congressionol Research Service, U.S. Librory of Congress (1982).
} 
Coal is already a pivotal resource in electricity generation, and has the potential of becoming a major contributor to gaseous and liguid synfuels in the long term. LLNL's program in one aspect of coal research, underground coal gasilication, has over the past 10 years become a leading promam in this field. It has continued to receive support from both the concerned industries and the Gov. ernment, although Government support of gasificrition research at LL,NL, has declined from over $\$ 3$ million to under $\$ 2$ million over the pust four years, in line with the deemphasis of such $R \& D$ in the DOE.

Under jround coal gasification shows considerable long-range promise both in terms of reserves and prices. Because of the current relatively low price of natural gas and its predicted adequate supply over the next 20 years, o nearterm large-scale commercial demonstration of underground coal gasificulion is not very likely Nonetheless, al costs considerably short of such $a$ dernonstration, field lests involving a realistic array of individual burns could be carried out. These, are needed in order to delermine the economic and environmental feasibility of underground gasification for cral resources below depths for economical strip mining. The shallow single-burn experments made to date do not delermine that leasiblity. Collabmration with one or more inciustrial purtners in such an extended test sisuld continue to be octively sought.

Beccuse of coal's current and likely future pivotal roje in electric power yeneration, an internal study was carried out to determine what LLNL efforts in the area oi coal ulilization might meet the criteria for new projects noted in the Introduction.

The study identified two areas of direct coal utilization which currently present a major hindrance to the optimal utilization of cual in this country and to which LLNL could bring its talents to bear. One area is the fouling and slagging produced during the coal combustion process. Major problems exist in the understanding of the behavior of mineral matter in coal during pyroly. sis and combustion which leads directly to fouling. slagging, and corrosion. Detailed proposals have been prepared which address problems in this area (e.g., behavior of mineral matter in coal combustion, the characterization of sulfur species in coal).

The other area concems the environmental impacts of enhanced coal utilization in the wertem U.S. The Laboratory possesses a state-of-the$a r$ capability to monitor and to understand environmental impacts. With increased utilization of western U.S. coal deposits at or near their source, the environnental impact of this utilization will need to be explored in detail. Environmental conditions in the west are quite different than in the east, where most studies have been accomplished. A series of integrated study areas has been proposed (e.g., transport of particlilate emissions, thrmical transformation of aerosols). These will need more work to formulate specific projects and to identify funding sources. The Committee recommends that this be done by the Energy and Resource Program Associate Director.

All lossil energy utilization hos an impact on the environment and existing LLNL energy projects have traditionally iunded some environinental work. Other work has been done collaboratively with energy projects but funded through tho DOF. Office of Health and Enivironmental Research Although funded by different sources, the prasiams should be coupled technically at the [uboratory. The Conmittee recommends that the Associcte Directors for E: ergy and Resource Programs, for Physics, and for Biorredical and Environmental Scienc + s work togethr $r$ on defining the aims and the scopes of these projects and monitoring them from both the program and the discipline (envirommental sciences) sides.

For over five years the Laboratory has participated in DOE's national $\mathrm{CO}$ : program doing significant experimental and theoretical research as well as aiding DOE in prugram management. The current tunding level is $\$ 1.9$ million of which about $70 \%$ is spent at LLNL. The possible longtern climatic effect of increased $\mathrm{CO}$, in the atmosphere is based on theoretical modeling of climate and has stibstantial uncertainties. It is currently estimated to be a $2-4^{\circ} \mathrm{C}$ increase in global average lemperature for a doubling of atmospheric 
work have resulted in significant technological advances for DOD. However, the funding level and the stability of the short-range reimbursable programs have fluctuated greatl). To use the DOE laborator sapabilities efficiently and to allow them to make a more significant and fundamerital contribution to conventional munitions, $\alpha$ stable and adequate funding base should be established.

LLNL has joined with Los Alamos National Labor story and Sandia Nctional Laboratories in proposing continuous fiunding for conventional munitions research and development at our laboratories. The Commiteo recommends that the Associate Director for Defense Systems work with DOD and DOE in establishing a munagement method that will insure that the Laboratory will carry out oppropriate Service missions without being put in the position of competing with industry. Szme arrar.gement similar io the MITRE and Aerospace funding and oversight method may be appropriate.

\section{Attitudes Towards the Nuclear Weapons Program}

While this is not a technical issue, it is so frequently brought up in discussions of long-range nuclear weapons program planning and so fundamental to the program that the Committee believes a brief statement of Luboratory views is needed here.

As noted in the Introduction, there has been a continuing consensus that the U.S. should continue to deploy nuclear weapons systems as required to support deterrence. The role of the Iaboratory continues to be to understand such systems and th:ir effects and to present the national leadership with what needs to be done to enable these systems to perform their mission. By staying with this role, the Laboratory has maintained its credibility with informed groups throughout the political spectrum. This credibility is essentiol if the Laboratory is to continue to do its job in this field.

Periodically, it a national policies on nuclear weanons are questioned and redefined. Such periods included the $\mathrm{H}$-bomb debate, the ABM debote and the various SALT debates. Now is such a period of debate. It is not possible to !orecast the outcon ne in dietail. One may note. however. that the factors (briefly stated. the vulnerubility of the U.S. and its allies to nuclear attack or threats, together with the lack of agreed, effective ways to resol:e peacefully all problems between rations\}. which led in the past to consensus on nuclear weaporis policies have not changed. It is, therefore, reasonable to expect that the Laboratory will be called on to do its work on nuclear weapons for some tine to conne.

During periods of controversy arıd reexamination, we believe is purticularly important to maintain, as the Laboratory has traditionally, a balanced, factual attitude townds technological developments, whether originated here or elsewhere, and towards proposed policies in the fields of nuclear weapons and arms control.

It is also important to inform the public about Laboratory weapons prograin to the extent security permits. The public includes fanilies and neighbors, the media, the interested segments of the University and school communitier and organizations of interested cjtizens. The Laboratory has increasingly opened itself to inspection and questions, spoken about its activities and encouraged its members to mett with groups which wanted to hear Lahoratory speakers. The results have been overwhelmingiy positive. Continuing this prugram in a serious, responsible wcy is an esseitial part of looking to our lorig-term future. 
$\mathrm{CO}_{2}$. The possibility of such a change could influence the U.S. and other nations to move from fossil fuels toward much greater reliance on nuclear energy. It is important to know what global climatic effects of $\mathrm{CO}_{2}$ to expect as soon as possible if there is to be on arderly change in world energy use pattems. The Laboratory is now acouiring a much expanded capability to model global climate, in part because of current resecrch on ciimatic effects of nuclear wor. The same modeing capabilities can and should be utilized at L.LNL to understand $\mathrm{CO}_{2}$ effects and the potential impact on energy research at the Laboratory. Experimental work on the effects of increased $\mathrm{CO}_{2}$ on plant growth (it is generally beneficial) should also be continued and expanded.

Although the present situation is sixch that large block funding for research on coal utilization is no: likely, a start involving a number of projects in this area is necessary if we are to maintain a viable program in fossil energy research. Our goal should be to maintain a focused and integrated program. The twin thrusts of coal combustion and environmental impact, including $\mathrm{CO}_{2}$ research, can provide this focus. A transition from smaller to larger and more focused projects will necessitate strong frogiam leadership at the $45-$ sociate Director level. 


\section{Additional R\&D Areas}

\section{Advanced Computers}

Elfective use of the most advanced supercomputers is an integral part of major Laboratory programs and most crucially of the nuclear weapons program. Until recently this was accomplished by relatively simple adaptation of existing codes to each new computing machine as it became crvailable. The appearance of vector computers during the 1970s introduced major complications into this process.

There are two main reasons. First, although the performance of the first vector machines was excellent on special kinds of problems, most codes ran slower, or marginally faster, than on the previous generation of serial computers. Secondly, modification of those codes to take advantage of vector capabilities was an arduous and complex task.

For the future, a move to multiprocessor machines is inevitable if the Laboratory is to take advantage of the potentially large improvements which parallel architectures promise. Nearly all "models" of future supercomputers envision them as highly parallel machines, in which a number of single processors simultaneously perform computotions. If both the hardware and soltware are efficient, the overall calculational time of the multiprocessor system can be almost as small as $1 / \mathrm{N}$ times the speed of one of the $\mathrm{N}$ processors. To approach this limit will require major innovations, because our present languages and algorithms have been largely based on sequential methods of computation.

The effort in going to multiprocessors will certainly be more complex than the serial-tovector transition. Programs must allow efficient scheduling of large numbers of simultaneous processors; algorithms need to take advantage of the porallelism inherent in future multiprocessors; and the computer languages must reflect these requirements. Const quently, software projects in several areas have been started to bridge the gap:

- Simulators for multiprocessors
- Parallel algorithms

- Modular code systems

- High-level languages

- Numerical methods

Although each of these study areas has produced interesting preliminary results, assuring significant progress will require several-fold increases in resources over current levels.

In addition, there are a number of more traditional solwware projects associated with efficiently using any new computer, including operoling system development, editors, innovative graphics, and a host of other features that contribute to a productive user interface. To ensure that the projects and study areas are aimed at meaningful improvements, a major elfort in instrumenting computers in order to measure the actual patterns and characteristics of their use is needed.

At present, LLNL activities are largely restricted to programmatic work designed to provide near-term receptiveness for the next supercomputer acquired by LLNL. There is a likely major payoff in increasing this effort and broadening it to encompass the full array of soltware issues ronsed by the changeover to a porallel computing environment.

In addition to developments in software, there are many hardwore and architectural issues that will determine the capabilities of future multiprocessor supercomputers. The speed and size of a single processor, the time for processors to communicate, and the optimal number of processors are all factors that are crucial, and on which large industrial and acodemic research efforts are under wGY. LLNL's $S-1$ project is aimed of addressing several of these problems. Conceptually, the $\mathrm{S}-1$ is centered on the development of a set of design tools, SCALD, which suppost the rapid prototyping of general-purpose digital circuitry. When fully developed, these tools will support the rapid design and physical implementation of complete multiprocessor systems. Thus, different kinds of multiprocessor architectures could be explored and tested to define the optinal configurations for solving different classes of problems. 
Work on the S-l to date has led to new insights in these areas. Much more can and should be done.

\section{Genetic Engineering}

A Genetic Engineering Subcommittee was formed by the Long-Range Planning Committee and the Biomedical Sciences Division to evaluate LLNL's potential use of recombinant DNA and monoclonal antibody technologies. The Subcommittee was composed of biomedical scientists and of representatives of other programs interested in possible nonbiological applications of the technologies at LLNL.

Recombinant DNA technology permits the combining of genes, regulatory fragments, and carrier DNA from different sources into a single molecule. The recombined molecule can be introduced into a bacterium or higher cell, where the DNA or the protein for which it codes can be replicated to high yields. The products can then be recovered and purified for a wide variety of applications. LLNL has recently begun an effort in recombinant DNA. At present the effort is small, and the experience level quite limited.

Monoclonal antibody technology frcilitates the detection and quantity production of proteins which bind to given molecules with high specificity and affinit $y$. These proteins are called antibodies. New techniques permit a multitude of different antibodies to be screened, a particular pure antibody to be selected out, and the cells that produce it to be mass-cultured through cloning techniques. From such cultures large quantities of absolutely pure, specific antibody can be obtained. LLNL has been active in the study of monoclonal antibodies for the past two years.

The Biomedical Sciences Division regards both recombinant DNA and monoclonal antibody technologies as critical tools for a variety of important biological programs within the Division. The Subcommittee concluded that these two biotechnologies hold broad promise for programmatic usefulness at LLNL, both within and outside of the Biomedical Sciences Division.

The Sibcommittee generated $a$ list of potential applications for biotechnology at LLNL, con- centrating on areas outside the scope of the Biomedical Sciences Division. The selection of topics was based on two criteria: the judgment of biomedical scientists that the projects might be biologicully feasible in the not-too-distant future. and the judgment of representatives of the applications areas that the projects would fill a significant need, either inside LLNL or in the national context. Nonbiomedical applications areas which the Subcommittee has judged of potential interest to a broad range of LLNL programs include use of recombinant DNA techniques to ccomplish elemental leaching in aqueous environments, detoxification of contaminated soil areas and concentrated toxic-chemical stockpiles, and liquefaction or depolymerization of fossil fuels. Monoclonal antibody technology could be used in sensitive chemical monitoring systems, detectors for high explosives, and in a variety of security and intelligence applications.

In the area of Laboratory experiments in the new biotechnology fields, the Subcommittee sees potential at LLNL for making substantial innovations in instrumentation and computational tools. The Laboratory is capable of interdisciplinary efforts of a type still un:usual in many biological research facilities. One would envision that a vigorous LLNL biotechnology research program could lead to the development of significant new experimental tools. These would be of considerable help to the genetic engineering community at large.

For the long-range applications of both recombinal it DNA and monoclonal antibody technology at LLNL, it is recommended that an evolutionary strategy be aclopled. The recommended steps are as follows:

- Build up and maintain strong core groups in recombinant DIJA and monoclonal antibodies research. These should remain within the Biomedical Sciences Divisicn and will begin by fulfilling programmatic needs within important ongoing biomedical projects.

- Over the next five years, evaluate and plan for promising biolechnology applications to new and ongoing LLNL programs. To do this, the core groups descriter above will need to be 
expanded to include needed expertise in appropitate applications areas.

- Begin research on appropriate new applications of biotechnology as they are identified. If the applications are well chosen, it is anticipated that the preliminary research and scoping studies will form the basis for accuisition of outside funding within five years. In the area of monoclonal antibodies, development of antigen activated electrical circuits would represent the first step toward applications to andlytical immunochemistry instrumentation in general.

\section{Space Nuclear Power and Other Space Activities}

In the past year or so, there has been interest in compoct high (about $100 \mathrm{~kW}$ electric and greater) power sources to meet possible future DOD space power needs. A National Academy of Sciences study and a number of other working groups under DOD, NASA, and/or DOE sfronsorship have been investigating military requirements for high powers and the available technologies and desirable approaches to meet the needs. It is likely, though not yet formally decided, that a program to develop a nominal $100 \mathrm{~kW}$ electric space reactor will be established.

The Jet Propulsion Laboratory is managing a project to provide engineering designs for space reactors. Four industrial reactor designers are competing on conceptual designs. It is expected that two wili be funded for detailed engineering studies. The overall program is funded at about $\$ 14$ million for 1984. Los Alamos has a key role in this program, but not as reactor designers. The longer term future (beyond about 1986) of this efforl vill depend on establishing firm requirements for the power source in one or more applications.

Even though it has ben 15 years since the Laboratory was involved in space power, there remains expertise here among former project members and in the general technologies important to the field. Laboiutory people have provided thr: current space program participants with the benefit of their experience and the available idocumentation on LLNL work on space reactors. They have also given their advice and comments on proposed new programs.

At this time there does not appear to be an opportunity for LLNL to become heavily involved in the space nuclear reactor program. The Laboratory has no unique contribution to make to the development of a $100 \mathrm{~kW}$ electric source. There is some possibility, however, that a more advanced reactor at the megowatt level or higher, using different materials and operating at higher temperature, will eventually be required. LLNL could well contribute to that development. In the meantime, the Laboratory should continue to assist the program, especially in the areas of systems, materials, and safely.

In addition to space nuclear power, there are likely to be other opportunities for the Laboratory to contribute to national space pragrams. Given continued prosperity and peace, space programs are likely to experience a revival. They have large, unexploited scientific, civilian and military putential. The Committee did not make $\alpha$ study of this potential. Such a study could have fruitful results. Appropriate participating elements of the Laboratory would include the quantum optics groups, the LLNL branch of the Institute of Geophysical and Planetary Physics and other astrophysics groups, the engineering and scientific groups with previous space experience, and the onguing defensive systems study group.

\section{Modeling the Global Atmosphere}

The Laboratory's two major technical areas, delense and energy, both have programmatic aspects that require an understanding of global atmospheric phenomena. For instance, as discussed in the Delense Subsection on the Global Effects of Nuclear War, a major nuclear war could produce atmospheric changes that would significantly alter ambient conditions at the earth's surlace. Continued worldwide energy generation 
by fossil fuels may generate enough carbon dioxide and other trace gases to cause the temperature at the earth's surface to rise gradually over the coming decades. In addition, the generation and spread of acidic moisture (acid rain) appears to be a significant and even more near term problem involving atmospheric physics though at the "mesoscale" rather than giobal scale.

During the past year, in part on the basis of a Committee study, work on the glotal climatic effects of nuclear war was significantly expanded. As part of this work, a state-of-the-art capability in global circulation modeling is being introduced into the Laboratory. Considerable improvement in capability to model plume-scale and mesoscale dynamics as well as in the understanding of the physics and chemistry of atmospheric injectants should also result from carrying out this project.

The Cummittee endorses a continuation of the current project oriented work, and in addition recommends an eilort to gradually develop a more broadly based modeling program. In particular, the Laboratory's capability to model turbulence, atmospheric chemistry. coagulation and scavenging processes, etc., should be increased.

\section{Artifiziol Intelligence}

Artificial Intelligence (AI) can be characterized as investigations into how computers can be made to carry cut mental tasks which are qualitatively different (in the investigator's view) from those they have traditionally done. The main investigations to date have dealt with the utilizatior of expert knowledge such as of lcw, medical diagnosis, resource exploration, game playing such as checkers or chess, and pattem recognition. Much of what investigators learn has to do with clarification of human mental processes.

The techniques of Artificial Intelligerice are potentially valuable in a number of areas of interest to the Laboratory. There are presently small independent projects in D Division, 2 Division. Chemistry and Materials Scierice, and elsewhere that use Al. Current total expenditures are on the order of a :iillion dollare rer year. The S-1 Mark IIA, in addition to its more conventional computational features, was designed as an effective AI machine. Numerous additional AI applications for LLNL hove been suggested, but not pursued as yet. Sandia and Los Alamos are both acquiring AI expertise and exploring applications of the sort generally interesting to LLNL.

AI as a separate programmatic activity does not seem timely for LLNL now. It can, however, be of value in existing programs, as is evidenced by the several ongoing projects. At present the number of people at the Laboratory trained ir or otherwise knowledgeabls in AI is quite limited. There is no central focus of AI activities, and a project leader who feels AI can help his work tends to pursue his own course.

To best utilize existing AI expertise at LLNL and mutually benefit from the experience in various Al projects, some informal coordination may be in order. The Computation or Electronics Engineering Department might take on that role. It should also review and select the most promising research topics and recommend levels of support from the programs or cther scurces. 


\section{Future Long-Range Planning Activities}

The L-RPC activity has proved useful in several ways: as a catalyst for management decisions, particularly in areas which overlapped several prcgrams and which, though important, may not have been at the top of anyone's agenda; as an opportunity for its members, who are senior laboratory technical leaders, to look broadly ot Laboratory problems and prospects; as a means of having outside experts come and talk to L-RPC members and other members of management about the future; and as a forum for interested Laboratory personnel to make inputs bearing on the future of the Laboratory.

The work of the L-RPC has required the commitment of considerable time from Committee members, all of whom are busy people. It was decided early to do the work mainly through volunteer activities of people presently engaged in the Laboratory's scientific and engineering management, in order to avoid unrealistic recommendations and the development of an adversary attitude hetween "planners" and "doers." This approach has worked well.

There is agreement among L-RPC members that the following steps are desirable:

1. A Laboratory-wide planning activity should be continued.

The benefits from this activity (in terms of calling attention to decisions, increasing the level of common information on likely future projects, meeting employee expectations that planning takes place and educating present and future leaders) seem worth the cost in time and effort.

2. The visitors' program should be continued.

Approximately once a month for the past two years, visitors invited by the L-RPC, including present and former Government officials, senior military officers, corporate executives and planners, etc. (Appendix 2). have participated in small, round-table disrussions with Laboratory programmatic leaders and planners. This program has been useful in a number of ways, and was the most popular of the
L-PPC's activities. It can be continued through the office of the Associate Director at Large.

3. Intercaction between program lecrders and academic policy planners should be increased. especially in the delense area.

Academic policy planners include faculty, students, and visiting scholars, many from key Government policy agencies and the Milita:y Services. They are associated with major universities, often in special institutions such as Harvard's Kennedy School of Govemment. The interaction of the Laboratory with this community, some of which has always taken place. can be increased to the benefit of both sides through such means as internships, summer or shorter-term studies, and occasional attendance of present or potential Laboratory leaders at these institutions.

4. For existing programs, the program leaders must continue to assume the responsibility for long-range planning in the broadest sense. For areas which do not fall within any program's scope, a new mechanism is needed.

What future experimental tacilities are needed and for what program objectives? What future weapon systems will be of importance? What computer research should be done? Such questions clearly fall within the cregis of present Associate Directors and should be worked on by their organizations subject to the Director's review. In addition. Associate Directors can and hove successfully taken on questions in areas bordering their own major thrust areas, such as future applications of quantum optics or the need for conventional munitions R\&D. Given the organization of the Laboratory, the Associate Dirf,ctors are also in the best position to work on those questions.

There remain some major areas for which new planning mechanisms are needed. In the case of nuclear power, studies of the hybrid breeder, nonaqueous reprocessing arid new reactor types were camied out under L-RPC sponsorship, but they will need to be contmued beyond 
this year. In the field of energy more generally, studies are needed to better understand the economic and other assumptions underlying present and proposed Laboratory programs. A broad look should also be iaken of the possible Laboratory contributions in space $R \& D$.

A mechanism for the assessment and, if needed, the modification of the way the Lahoratory does supporting research is also needed. The responsibility for determining what this supporting research should be in the various disciplines is already clearly assigned, but the methods for recruiting, providing direction, establishing priorities, etc. would benefit from being reviewed and assessed on a Laboratory-wide brasis. The L-RPC, in cooperation with the leaders responsible for supporting research at the Laboratory has established a task force to carry out a review and prelimirusry assessment. 'The task force is looking at such institutions as the Bell Laboratories and IBM in addition to looking within the Laboratory. This work should be continued.

To carry out the Laboratory's future planning functions, the Committee has three recommendations:

1. For existing programs and related technical fields, the prugram leaders must continue to assume the responsibility for long-range plan- ning in the broadest sense. Each of the programmatic and discipline Associate Directors should evaluate the adequacy of their planning for the future and make adjustments if necessary.

2. In areas outside existing programs, or where substantial overlap exists between program interests, the Associate Directors concerned. under the chair of the Director or an Associate Director, should sponsor groups to carry out studies and recommend action. This is specifically needed now in the areas of energy and space.

3. Every few years a new Long-Range Planning Committee, composed of up-and-coming managers and other knowledgeable concerned protessionals, should be constituted by the Director to take a Laboratory-wide lank at now and existing programs in the light of recent national trends, and to follow up on previous long-range planning recommendations. Such periodic activities give management a different and informed view of Laboratory prospects. They are also an excellent means of educating present and future top management and scientific leadership. They would, however, lose much of their value if they were unduly institutionalized. 
The following list of visitors to LLNL met with the L-RPC on the indicated dates. Most were invited by the Committee but in some cases, they were at the Laboratory for other reasons and the Cor.mittee took advantage of the visit to meet with them.

\begin{tabular}{|c|c|}
\hline Date & Visitor \\
\hline Nov. 20,1981 & Dr. Harris Mayer, Aerospace Corporation \\
\hline Dec. 28, 1981 & Dr. Eugene Fubini, Frivate Consultant, Former Asst. Secretary of Delense \\
\hline Jan. 26, 1982 & Dr. Henry Kelly, Office of Technology Assessment, formerly of SIRI \\
\hline Feb. 1,1982 & Prof. John Deutch, Provost of M.I.T. \\
\hline Feb. 19,1982 & Dr. Glenn Werth, Woodward-Clyde Consultants \\
\hline Eeb. 22. 1982 & Prof. Charles Hitch, President Emeritus of University of Califomia \\
\hline March 1, 1982 & Dr. Charles Zraket, Executive V.P., MITRE Corporation \\
\hline March 5, 1982 & Dr. William Brown, Hudson Institute \\
\hline March 11. 1982 & Dr. Arnold Kramish, High Frontier \\
\hline March 15, 1982 & Admiral lsaac Kidd, JSN (Retired), former CINCLANT. \\
\hline March 18, 1982 & Prof. David Rose, M.I.T. (Director's Distinguished LezILrer) \\
\hline April 5, 1982 & Dr. Daniel Fink, V.P. of General Electric \\
\hline Apri 6. 1982 & PTof. Wallace Broecker, Columbia University \\
\hline May 3, 1982 & General Andrew Goodpastor, USA (Retired), former SACEUR \\
\hline May 18, 1982 & $\begin{array}{l}\text { Dr. Harold Brown, Johns Hopkins University, former Secretary of Delense (Director's } \\
\text { Distinguished Lecturer) }\end{array}$ \\
\hline May 24,1982 & Dr. Herman Postma, Director, ORNL \\
\hline May 26, 1982 & Dr. Woody Cunningham, MITRE Corporation \\
\hline July 21,1982 & Rear Admiral L. S. Kollmorgen, USN, Chief of Naval Resectrch \\
\hline Aug. $10-11,1982$ & Dr. Robert Hirsch, EXXON Corporation \\
\hline Aug. 11, 1932 & Dr. Gerald Tape, Associated Universities, former AEC Commissioner \\
\hline Sept. 10, 1982 & General Donn Starry, USA, CINC Readiness Command \\
\hline Sept. 21,1982 & General George Blanchard, USA (Retired), former Commander U.S. Army Europe \\
\hline Sept. 27, 1982 & General Lew Allen, USAF (Retired), Director of JFL, former Air Force Chieí of Staff \\
\hline Sept. 28, 1982 & Dr. David Heebner V.P. of Science Applications Incorporated \\
\hline Oct. 21, 1982 & Admiral Kinnaird McKee, USN, Director of Noval Nuclear Propulsion \\
\hline Oct. 25,1982 & $\begin{array}{l}\text { General Russell Dougherty, USAF (Retired). Private Consultant, former commander } \\
\text { SAC }\end{array}$ \\
\hline Oct. 28,1982 & M. King Hubbert (Director's Distinguished Lecturer) \\
\hline Nov. 10, 1982 & Prof. Charles Townes, U.C Berkeley (Director's Distinguished Lecturer) \\
\hline Nov. 12,1982 & Prof. William McMillan, UCLA \\
\hline Nov. 22, 1982 & Rear Admiral Robert Wertheim, USN (Retired), V.P. of Lockheed Corporation \\
\hline Nov. 23, 1982 & Dr. Dixy Lee Ray, former Governor of Washington and Chairman AEC \\
\hline Feb. 4.1983 & Ptof. John MCCarthy, Stanford University \\
\hline Feb. 23,1983 & Dr. Robert Frülskiky, U.C. Berkeley \\
\hline Apri] 5, 1983 & Dr. Soloman BuchsLaum, Executive V.P. of Bell Laboratories \\
\hline May 20, 1983 & Dr. David Barstow, Schlumberger Doll \\
\hline June 10,1983 & Dr. Alvin Weinberg, Director of the Institute of Energy Analysis \\
\hline July 11-12، 1983 & Admiral Bobby Inman, President of MCC, former Deputy Director of CìA \\
\hline Aug. l. 1983 & Dr. Sidney Fernbach, Control Data Corporation \\
\hline
\end{tabular}


Aug. 29, 1983 Prof. Albert Carnesale, Academic Dean of the Kenredy School of Government

Dec. 5-7, 1983

John W. Simpson, Simpson Business Services, Inc., formerly of Westinghouse Corporation

Dec. 12, 1983 General Edward C. Meyer, USA (Retired), former U.S. Army Chief of Staff 


\section{LONG-RANGE PLANNING COMMITTEE ESTABLISHED}

I am establishing a long-range planning comittee at the Laboratory to help me and the Associate Directors assure that the Laboratory remains a major contributor to national RaD and a challenging place to work. The committee will thereby assist in better meeting the Laboratory's longtime contractual responsibility "to encourage basic scientific progress and to assure adequate technical accomplishment in the interest of national Jefense and public welfare."

The committee will carry out the following tasks:

1. Identify, analyze and evaluate possible new programs appropriate to the Laboratory taking into account significant national needs and relevant scientific developments.

2. Help the Director evaluate the $13 \mathrm{kely}$ areas of major programmatic change for the Laboratory for the next ten years.

3. Assist the Director in developing an improved overall picture of the laboratory's future needs with regard to people, sites and facilities.

Michael May will chair the committee. Carl Haussmann is vice-chairman. Members are Robert Andrews, Charlie Bender, Robert Borchers, Lynn Cleland, Robert Clough, James Davis, John Nuckolls, Robert Schock, and Bruce Tarter. The committee will carry out its work with the help of 2 small staff and of people assigned by the various Departments and Divisions. The assigned people will carry out studies of various areas on a full or part-time basis. The comittee will report to me and work with Associate Directors and others as required to assure the development of realistic plans consistent with our responsibilities, capabilities and interests. The Comittee is estabijshed for a period of two years, after which the process will be reviewed.

Mike May has already had informal discussions with a number of people at the Laboratory to solicit suggestions for areas of interest and inquiry for the project. Further suggestions and ideas from interested Laboratory personnel are encouraged and welcome. Contact Mike May or other members of the comittee.

Roger E. Batze]

Director 